\title{
Oxygen isotope ratios in olivine from the Hawaii Scientific Drilling Project
}

\author{
John M. Eiler \\ Division of Geological and Planetary Sciences, California Institute of Technology, Pasadena \\ John W. Valley \\ Department of Geology and Geophysics, University of Wisconsin, Madison \\ Edward M. Stolper
Division of Geological and Planetary Sciences, California Institute of Technology, Pasadena
}

\begin{abstract}
Oxygen isotope ratios of olivine in 23 tholeiites from the Hawaii Scientific Drilling Project (HSDP) core (15 from Mauna Kea, 8 from Mauna Loa) and three samples of outcropping subaerial or dredged submarine Mauna Kea lavas have been measured by laser fluorination. The $\delta^{18} \mathrm{O}$ values are $4.6-5.4 \%$, confirming previous observations that some Hawaiian lavas are derived from sources with $\delta^{18} \mathrm{O}$ values lower than typical upper mantle $\left(\delta^{18} \mathrm{O}_{\text {olivine }} \approx 5.2 \pm 0.2 \%\right)$. The Mauna Kea-Mauna Loa transition marks a shift from $\delta^{18} \mathrm{O}$ values lower than the mantle average in Mauna Kea olivines $(-4.8)$ to more typical mantle values in Mauna Loa olivines. Lavas containing olivines with $\delta^{18} \mathrm{O}$ values similar to the typical upper mantle are associated with more "primitive" or less depleted radiogenic isotope characteristics; i.e., with higher ${ }^{3} \mathrm{He} /{ }^{4} \mathrm{He}(>13 \mathrm{Ra})$, higher ${ }^{87} \mathrm{Sr} /{ }^{86} \mathrm{Sr}(>0.7036)$ and lower $\varepsilon_{\mathrm{Nd}}(<6.5)$, and with ${ }^{206 \mathrm{~Pb} / 204} \mathrm{~Pb}$ ratios less than $\sim 18.3$. These relationships indicate that the $\delta^{18} \mathrm{O}$ values of the relatively enriched source components of the Hawaiian plume sampled by Mauna Loa lavas are comparable to (or greater than) the mantle average. This conclusion is supported by $\delta^{18} \mathrm{O}$ values of olivine from other high ${ }^{3} \mathrm{He} /{ }^{4} \mathrm{He}$ islands, which are also comparable to the upper mantle average. The low $\delta^{18} \mathrm{O}$ values in Hawaiian lavas are derived from a source having more MORB-like, or depleted, $\mathrm{He}, \mathrm{Nd}$, and $\mathrm{Sr}$ isotope ratios, but more radiogenic $\mathrm{Pb}$ than is seen in the Mauna Loa lavas Assimilation of ${ }^{18} \mathrm{O}$-depleted lower oceanic crust from the underlying Pacific crust by hot, $\mathrm{MgO}$-rich parental magmas or melting of older, recycled oceanic crust entrained in the Hawaiian plume are both possible sources of this ${ }^{18} \mathrm{O}$-depleted, MORB-like component in Hawaiian magmas.
\end{abstract}

\section{Introduction}

Oxygen isotope ratios provide important constraints on the sources and processes of oceanic volcanism. Hawaiian lavas are unusual relative to other oceanic basalts in that they are the only significant occurrence of low- $\delta^{18} \mathrm{O}$ basaltic material ( $<5.7 \%$ for whole rocks and glasses) not known to have been modified by incorporation of crustal rocks [Kyser et al., 1982; Garcia et al., 1989, 1993] $\left(\delta^{18} \mathrm{O}\right.$ values are all reported relative to standard mean ocean water, SMOW). The only comparably voluminous oceanic basalts with low $\delta^{18} \mathrm{O}$ values are from Iceland, where such values have been attributed to mixing with partial melts of the existing hydrothermally altered basaltic pile [Sigmarsson et al., 1992; Hemond et al., 1993]. Small amounts of ${ }^{18} \mathrm{O}-$-depleted lava have been found on other ocean islands (e.g., Réunion, Ascension, Tenerife, the Cameroon line), but samples from these locations are dominated by higher values of $\delta^{18} \mathrm{O}$, and low values are not clearly associated with any particular mantle source as defined

Copyright 1996 by the American Geophysical Union.

Paper number 95JB03194.

0148-0227/96/95JB-03194\$09.00 by radiogenic isotope ratios (see data summarized by Harmon and Hoefs [1995]). The low $\delta^{18} \mathrm{O}$ values of Hawaiian whole rocks and glasses have been explained either as a characteristic of primitive, deep mantle [Kyser et al., 1982; Garcia et al., 1989] or as a property essentially unique to the mantle source or sources sampled by the Hawaiian plume [Garcia et al., 1993]. The second of these explanations implies that the sources of Hawaiian magmas represent a mantle component or reservoir distinct from those previously identified by radiogenic isotopes [e.g., Zindler and Hart, 1986]. The low $\delta^{18} \mathrm{O}$ signature could also plausibly be associated with a contribution to Hawaiian lavas by hydrothermally altered oceanic crust, either as an ancient recycled component [Hofmann and White, 1982; Cartwright and Valley, 1991] or as a contaminant from the underlying Pacific plate (as has been suggested based on radiogenic isotope evidence [Hegner et al., 1986; Tatsumoto et al., 1987]). The wide range of permissible explanations for the low $\delta^{18} \mathrm{O}$ component sampled in Hawaii reflects the fact that previous studies have not detected significant correlations between $\delta^{18} \mathrm{O}$ and other geochemical properties. The only previously observed correlation is that Hawaiian tholeiites commonly have lower $\delta^{18} \mathrm{O}$ values than alkali basalts [Kyser et al., 1982; Garcia et al., 1993]. 
However, $\delta^{18} \mathrm{O}$ values of the two lava types overlap, and few data demonstrate this relationship within individual volcanoes.

In this paper, we report results of a study of $\delta^{18} \mathrm{O}$ values of olivines from the Hawaii Scientific Drilling Project (HSDP) core (a $1 \mathrm{~km}$-deep drill core taken from near Hilo bay, Hawaii [Stolper $e t$ al., this issue]) and from a small number of outcropping subaerial and dredged submarine samples analyzed for comparison. In contrast to previous studies, we used the technique of laser fluorination. This method offers considerable improvements in accuracy and precision for the analysis of refractory minerals that have proven difficult to analyze by conventional fluorination techniques [Sharp, 1990; Mattey and Macpherson, 1993; Valley et al. , 1995]. This has allowed us to analyze olivine rather than whole rocks or glasses, which are more susceptible to alteration and lowtemperature isotopic exchange with water. In addition, as with all other geochemical studies reported in this volume, the HSDP core provides excellent stratigraphic control and opportunities to search for covariations among a variety of isotopic and chemical parameters. Only one previous study of Hawaiian lavas (that of the Loihi seamount [Garcia et al., 1993]) compared $\delta^{18} \mathrm{O}$ values with other isotopic ratios, yet such comparisons will ultimately be key to understanding the significance of oxygen isotope variations among the sources of basaltic volcanism.

\section{Sampling and Analytical Techniques}

Samples were selected from a subset of those analyzed for major and trace elements and radiogenic isotope ratios, as reported by others in this special section [Baker et al., this issue; Garcia, this issue; Hauri et al., this issue; Hofmann and Jochum, this issue; Kurz et al., this issue; Lassiter et al, this issue; Rhodes, this issue; Yang et al, this issue]. Samples are dominantly olivine-rich tholeiites but include representative transitional and alkalic lavas. The selected samples extend over the entire length of recovered core and include the extremes in radiogenic isotope ratios identified by other investigators [Hauri et al., this issue; Kurz et al., this issue; Lassiter et al., this issue]. Additional samples of Mauna Kea lavas analyzed for comparison to drill core samples include two subaerial samples from the Kaawalii gulch and one submarine sample dredged from the east rift zone.

Samples were coarsely crushed in a jaw crusher and the $0.589-0.991 \mathrm{~mm}$ fraction was isolated by sieving, cleaned of dust by blowing with compressed air and/or ultrasonicating in deionized $\mathrm{H}_{2} \mathrm{O}$, and dried under a heat lamp. Approximately 5-20 mg of olivine ( $10-20$ fragments) were separated by hand-picking under a binocular microscope, avoiding fragments containing visible inclusions and alteration products. It was possible in all samples to separate olivine fragments containing $\leqslant 1-3 \%$ alteration phases and mineral or melt inclusions (based on visual estimates). There were no noticeable differences in inclusion content between separates.

Olivine separates were analyzed by laser fluorination at the University of Wisconsin, Madison, as described by Valley et al. [1995]. Duplicate analyses were made for two-thirds of the samples, with an average deviation from the mean for replicates of $\pm 0.07 \%$. A Gore Mountain garnet standard (UWG-2), previously analyzed conventionally and calibrated by laser fluorination against NBS-28 quartz, was run concurrently with the olivine samples. Analyses of UWG-2 conducted during the period of this work were within analytical uncertainty of the accepted value (Table 1; no correction has been applied to the data) and reproducible to $\pm 0.06 \%$ ( $1 \sigma$, $n=18$ ). Reproducibility of duplicates is comparable to analytical precision, indicating that little or no isotopic variability exists among grains within a given sample (each analysis is of one to five olivine fragments). Multiple analyses of fragments from a single grain of San Carlos olivine yielded a $\delta^{18} \mathrm{O}$ value of $5.26 \pm 0.05 \%(n=7)$, comparable to the average for olivine from mantle peridotite xenoliths (5.19\%o [Mattey et al, 1994]).

\section{Results}

Olivine from the HSDP core and related samples has $\delta^{18} \mathrm{O}$ values between 4.64 and $5.39 \%$ (Table 1 ). This range of $\sim 1 \%$ is comparable to that previously found for Hawaiian whole rocks and glasses [Kyser et al., 1982; Garcia et al., 1989, 1993]. However, $\delta^{18} \mathrm{O}$ values from this study show consistent differences between Mauna Loa and Mauna Kea and correlate with radiogenic isotope and trace element ratios, providing new constraints on the source of the distinctive (i.e., low $\delta^{18} \mathrm{O}$ ) Hawaiian oxygen isotope signature.

Figure 1 shows the variation of $\delta^{18} \mathrm{O}$ of olivines with depth in the HSDP core. Most of the samples from the Mauna Kea section are within analytical uncertainty of each other, and the entire population averages $4.80 \pm 0.09$. Outliers among the Mauna Kea samples (e.g., R347 and R413) also differ from

Table 1. Oxygen Isotope Ratios in Olivine From HSDP Lavas and Related Samples

\begin{tabular}{lclcl}
\hline Sample & Depth, $\mathrm{m}$ & \multicolumn{1}{c}{$\boldsymbol{\delta}^{\text {I8 }} \mathrm{O}$} & Average & Unit \\
\hline R55-0.75 & -74.0 & 5.21 & 5.21 & ML, unit 11 \\
R103-2.65 & -147.7 & 5.19 & 5.19 & ML, unit 17 \\
R129-5.50 & -210.8 & 5.27 & 5.27 & ML, unit 32 \\
R133-6.10 & -223.1 & $5.37,5.30$ & 5.33 & ML, unit 34 \\
R135-3.50 & -228.8 & 5.20 & 5.20 & ML, unit 35 \\
R142-1.60 & -241.1 & $5.49,5.28$ & 5.39 & ML, unit 37 \\
R150-0.05 & -260.0 & $4.95,5.10$ & 5.03 & ML, unit 40 \\
R153-3.05 & -268.2 & $5.23,5.04$ & 5.13 & ML, unit 43
\end{tabular}

$\begin{array}{lllll}\text { R160-5.75 } & -289.0 & 4.69,5.04 & 4.87 & \text { MK, unit 47 } \\ \text { R164-1.55 } & -299.3 & 4.76 & 4.76 & \text { MK, unit 49 } \\ \text { R189-8.50 } & -367.6 & 4.91,4.74 & 4.83 & \text { MK, unit 64 } \\ \text { R212-0.40 } & -424.1 & 4.88,4.63 & 4.76 & \text { MK, unit 72 } \\ \text { R215-7.2 } & -433.8 & 4.76 & 4.76 & \text { MK, unit 80 } \\ \text { R221-0.6 } & -451.3 & 4.81,4.74 & 4.78 & \text { MK, unit 88 } \\ \text { R243-8.40 } & -514.2 & 4.51,4.76 & 4.64 & \text { MK, unit 103 } \\ \text { R259-0.8 } & -542.2 & 4.82 & 4.82 & \text { MK, unit 109 } \\ \text { R303-3.00 } & -623.4 & 4.73 & 4.73 & \text { MK, unit 126 } \\ \text { R347-1.0 } & -738.7 & 5.04,4.85 & 4.95 & \text { MK, unit 152 } \\ \text { R365-0.05 } & -781.2 & 4.73,4.71 & 4.72 & \text { MK, unit 159 } \\ \text { R413-1.40 } & -910.3 & 4.97,5.01 & 4.99 & \text { MK, unit 189 } \\ \text { R446-2.40 } & -994.7 & 4.72,4.66 & 4.69 & \text { MK, unit 211 } \\ \text { R463-7.0 } & -1043.7 & 4.92,4.91 & 4.91 & \text { MK, unit 224 } \\ \text { R466-5.0 } & -1052.4 & 4.71,4.96 & 4.83 & \text { MK, unit 227 }\end{array}$

\begin{tabular}{lllll} 
MK1-8 & - & $5.04,5.05$ & 5.05 & MK, submarine \\
KI-3 & - & $4.54,4.75$ & 4.64 & MK, Kaawalii Gulch \\
KI-8 & - & 4.66 & 4.66 & MK, Kaawalii Gulch \\
\hline
\end{tabular}

All values of $\delta^{18} \mathrm{O}$ in units of permil relative to SMOW. UWGMT-2 $=5.76 \pm 0.06 \%, 1 \sigma, n=18$; calibrated value $=5.8 \pm 0.1 \%$. San Carlos -1 $=5.25 \pm 0.05 \%, 1 \sigma, n=7$. "ML" is Mauna Loa; "MK" is Mauna Kea. 


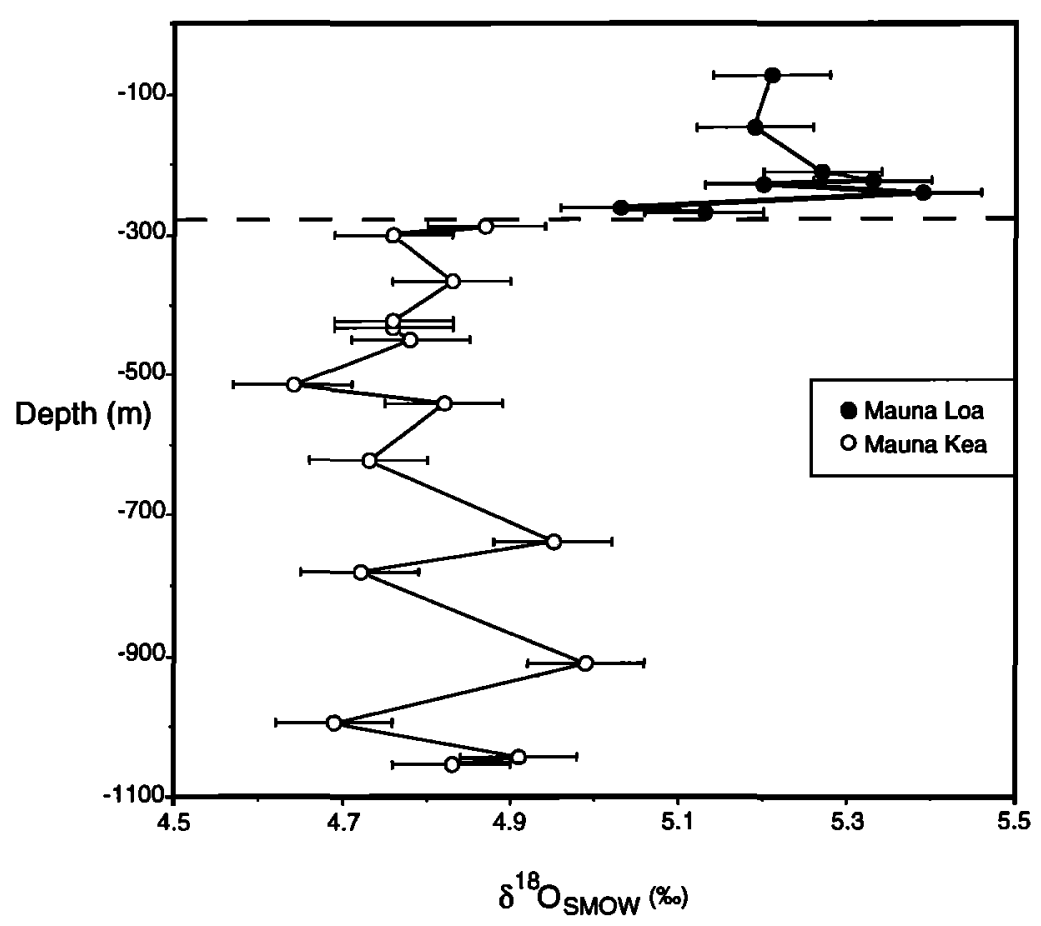

Figure 1. Values of $\delta^{18} \mathrm{O}$ measured in olivine from lavas from the Hawaii Scientific Drilling Project (HSDP) core versus depth in the core. The dashed line marks the location of the contact between Mauna Loa and Mauna Kea lavas [Stolper et al., this issue]. The samples from the Mauna Kea section have significantly lower $\delta^{18} \mathrm{O}$ values than olivine from mantle xenoliths $(\sim 5.2 \%)$ Error bars show the average deviation from the mean for all replicate analyses $( \pm 0.07 \%$ o).

average values in radiogenic isotope ratios (see below), suggesting that these variations represent true excursions from the background average of Mauna Kea tholeiites and are not analytical artifacts. Olivine from the small number of outcropping subaerial and dredged submarine samples of Mauna Kea lavas included in this study span approximately the same range in $\delta^{18} \mathrm{O}$ as samples from the HSDP drill core (4.64-5.05). Across the Mauna Kea-Mauna Loa contact in the HSDP core, $\delta^{18} \mathrm{O}$ values increase to an average value for Mauna Loa of $5.22 \pm 0.11 \%$, with no overlap between the samples from the two volcanoes.

The variations of $\delta^{18} \mathrm{O}$ in olivine from the HSDP core and in other samples from Mauna Kea correlate with radiogenic isotope ratios measured on whole rocks for $\mathrm{Pb}, \mathrm{Sr}$, and $\mathrm{Nd}$ isotopes and on olivine separates for He isotopes (Figures 2a2d; radiogenic isotope data from Yang et al. [1994], Hauri et al. [this issue], Kurz et al. [this issue], and Lassiter et al. [this issue]). Higher values of $\delta^{18} \mathrm{O}(\sim 5.2 \%)$ in olivine correspond to lower $\varepsilon_{\mathrm{Nd}}$ and $\mathrm{Pb}$ isotope ratios and to higher ${ }^{3} \mathrm{He} /{ }^{4} \mathrm{He}$ and ${ }^{87} \mathrm{Sr} /{ }^{86} \mathrm{Sr}$. These correlations are strongest when data from both volcanoes are considered, but they are present and significant at the $88-98 \%$ confidence level in the $\delta^{18} \mathrm{O}$ vs. ${ }^{206} \mathrm{~Pb} /{ }^{204} \mathrm{~Pb}$ correlations in Mauna Loa and Mauna Kea and the $\delta^{18} \mathrm{O}$ versus $\varepsilon_{\mathrm{Nd}}$ and $\delta^{18} \mathrm{O}$ versus ${ }^{3} \mathrm{He} /{ }^{4} \mathrm{He}$ correlations for Mauna Kea (Figure 2).

Relationships between $\delta^{18} \mathrm{O}$ of olivine and major and trace element composition are shown in Figures 3a-3d. Whole rock chemical compositions are largely controlled by differences in olivine content [Rhodes, this issue; Yang et al, this issue]. Elemental ratios and mineral composition have therefore been emphasized in comparisons with the oxygen isotope ratios. Values of $\delta^{18} \mathrm{O}$ are not correlated with forsterite contents of olivine (Figure 3a; data from Baker et al. [this issue]) or with whole rock $\mathrm{Mg \#}$ (molar $\mathrm{Fe} /(\mathrm{Fe}+\mathrm{Mg})$ ) or $\mathrm{MgO}$ content (not shown). Values of $\delta^{18} \mathrm{O}$ do not correlate with alkalinity index (Figure 3b), in contrast with previous results [Kyser et al., 1982; Garcia et al., 1993]. Values of $\delta^{18} \mathrm{O}$ in olivines appear to correlate with highly incompatible trace element ratios, such as $\mathrm{Zr} / \mathrm{Nb}$, and $\mathrm{Th} / \mathrm{Nb}$ (Figures. 3c and $3 \mathrm{~d}$; data taken from Hofmann and Jochum [this issue]), but this just reflects systematic differences between Mauna Loa and Mauna Kea (i.e., trends are not seen within samples from each volcano). The lack of correlations between $\delta^{18} \mathrm{O}$ in olivines and the major element composition of the olivine, alkalinity, or major or trace element indicators of depth or degree of melting strongly suggests that $\delta^{18} \mathrm{O}$ is not significantly influenced by melting processes in the source or crystal fractionation. On the other hand, the correlations with radiogenic isotope ratios suggest that the $\delta^{18} \mathrm{O}$ values of the olivines reflect characteristics of the source(s) of the magmas.

No simple relationships exist between our results and those of previous studies of Hawaiian whole rocks and glasses [Kyser et al., 1982; Garcia et al., 1989, 1993]. Previous studies found all Hawaiian volcanoes from which a representative sampling was taken to have highly variable $\delta^{18} \mathrm{O}$, with no significant differences in ranges or averages from volcano to volcano and no correlations between $\delta^{18} \mathrm{O}$ and other isotope ratios. More recent study of oxygen isotope ratios in coexisting glasses and olivines from Kilauea [Garcia et al, 1995a] suggests that glasses have been shifted in $\delta^{18} \mathrm{O}$ by latestage processes and that they do not reflect values of mantlederived magmas. We will make no attempt to relate previous analyses of glasses to our results on olivine from this study. 

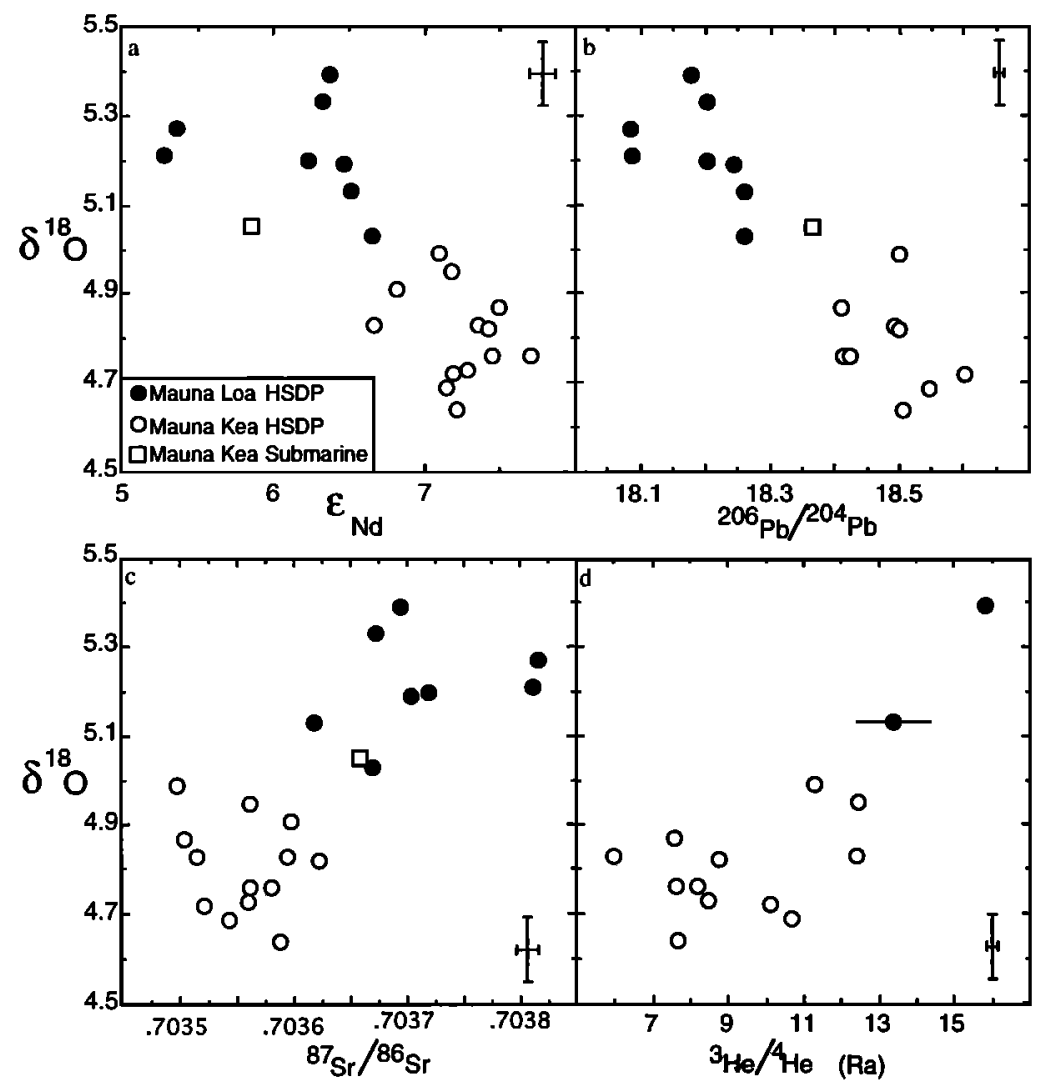

Figure 2. Values of $\delta^{18} \mathrm{O}$ measured in olivine from lavas from the HSDP core and a submarine sample from Mauna Kea plotted versus radiogenic isotope ratios [Yang et al., 1994; Hauri et al., this issue; Lassiter et al., this issue; Kurz et al. , this issue]. Oxygen isotope ratios are correlated with radiogenic isotope ratios, such that low- $\delta^{18} \mathrm{O}$ Mauna Kea samples have Nd and $\mathrm{Sr}$ isotope ratios characteristic of a more depleted source with MORB-like ${ }^{3} \mathrm{He} /{ }^{4} \mathrm{He}$ ratios, and more radiogenic $\mathrm{Pb}$. Error bars for $\delta^{18} \mathrm{O}$ values show the average deviation from the mean for all replicate analyses $( \pm 0.07 \%$ ). The error bars for radiogenic isotope ratios represent average reported precision from the primary reference (marked on datum if significantly larger than average). The square is a submarine Mauna Kea sample (MK1-8; Yang et al., 1994).

\section{Discussion}

\section{Evaluation of Olivine Xenocryst Contamination}

The principal complication in interpreting $\delta^{18} \mathrm{O}$ values of olivine from basaltic lavas is the possible presence of xenocrysts. Olivine grains showing at least minor strain (as seen in oscillatory extinction under crossed polars) are common in olivine-rich Hawaiian tholeiites [e.g., Helz, 1987; Wilkinson and Hensel, 1988; Clague and Denlinger, 1994; Yang et al., 1994; Baker et al., this issue; Garcia, this issue]. Strained olivine grains are present in thin sections of all samples analyzed in this study, but there is no correlation between $\delta^{18} \mathrm{O}$ and the abundance of these grains in samples for which detailed point counts are available [see Garcia, this issue]. Clearly exotic grains showing kink banding and/or planar inclusion trails are also present, but rare (estimated < $5 \%$ ) in thin sections of the samples we have analyzed and in other olivine-rich lavas from Mauna Loa and Kilauea [Wilkinson and Hensel, 1988].

Electron microprobe analyses of the more common, slightly strained olivines and of their inclusions (both in HSDP samples and previous studies) show them to be indistinguishable compositionally from unstrained grains. Both textural types of olivines are also characterized by forsterite contents that are variable but broadly appropriate to the whole rock chemistry of host lavas, by "normal" zonation, and by
$\mathrm{CaO}$ contents indicative of magmatic crystallization [Wilkinson and Hensel, 1988; Yang et al, 1994; Baker et al., this issue; Garcia, this issue]. Taken together, these lines of evidence suggest that the common, slightly strained olivines are either not exotic to their host lavas or crystallized from closely related liquids (perhaps in shared magma chambers or conduits). Consequently, we infer that the olivine grains analyzed in this study have $\delta^{18} \mathrm{O}$ values reflective of their host lavas or of closely related lavas.

This inference is supported by two other observations from this study: (1) Multiple measurements of $\delta^{18} \mathrm{O}$ in olivines from a given sample have the same average reproducibility as the analytical precision for standards, whereas differences of approximately ten times analytical precision are observed between olivines from different rock samples. (2) The $\delta^{18} \mathrm{O}$ values of olivines differ between the Mauna Loa and Mauna Kea samples and correlate with isotopic ratios for elements not contained in olivine; this would have to be fortuitous if samples contained appreciable quantities of isotopically exotic xenocrysts. This second line of reasoning is supported by analyses of Os isotope ratios in samples from the Mauna Loa section of the HSDP core [Hauri et al., this issue], which correlate with $\mathrm{Sr}, \mathrm{Nd}$, and $\mathrm{Pb}$ isotope ratios. Osmium is contained almost entirely in olivine in an olivine-bearing rock, and such correlations would be difficult to understand if a large fraction of the olivine grains were not indigenous to the flows 

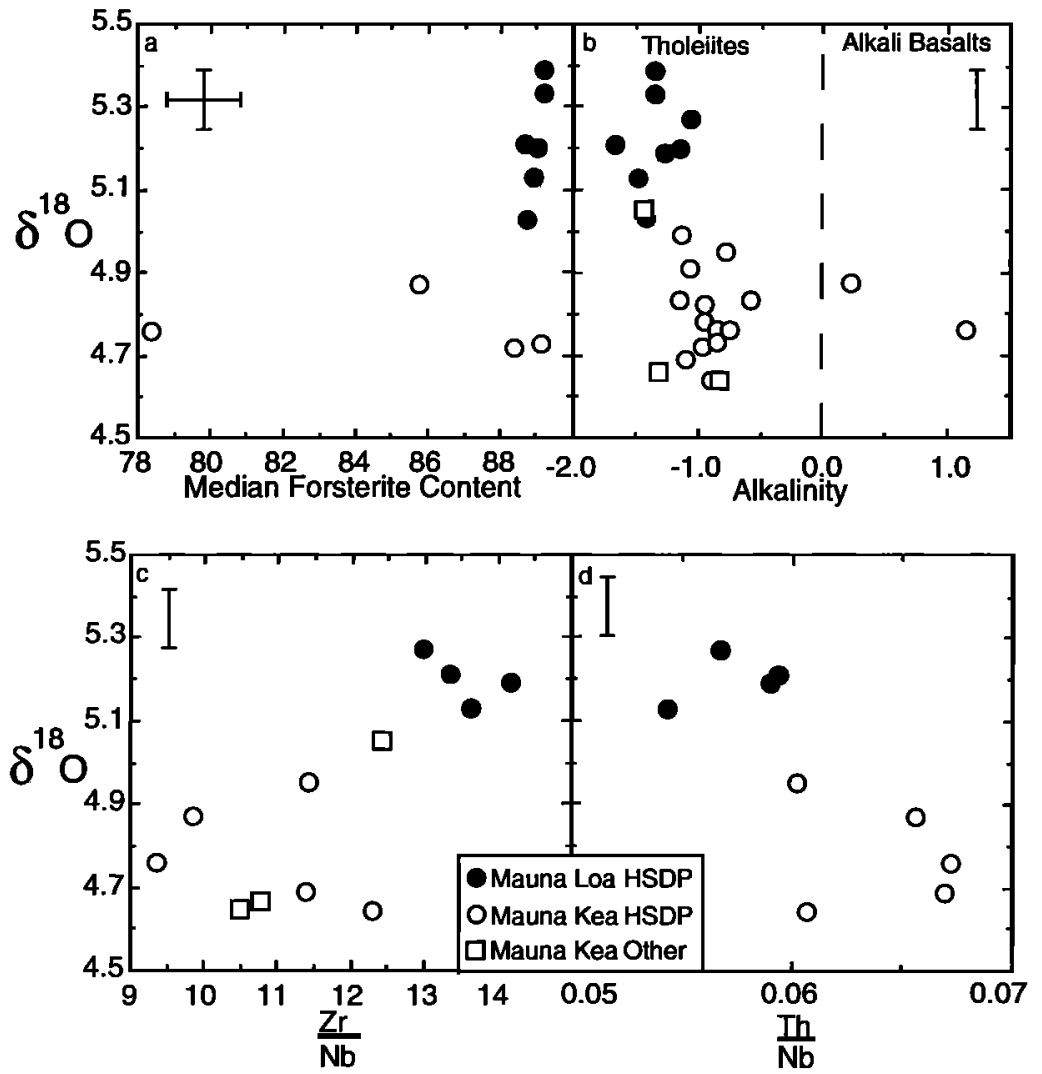

Figure 3. Values of $\delta^{18} \mathrm{O}$ in olivine from lavas from the HSDP core and other Mauna Kea samples, as functions of mineral and whole rock composition. Oxygen isotope ratios are not correlated with the forsterite content of olivine or whole rock alkalinity (Figures $3 \mathrm{a}$ and $3 \mathrm{~b}$; data reported by Baker et al. [this issue] and Rhodes [this issue]), but weakly correlated with trace element ratios (Figure 3b,d; data reported by Hofmann and Jochum [this issue]). Error bars for $\delta^{18} \mathrm{O}$ values show the average deviation from the mean for all replicate analyses $( \pm 0.07 \%$ ). Error bars for median forsterite content are $1 \sigma$ variations. Squares indicate outcrop or submarine samples of Mauna Kea lavas (Yang et al., 1994).

in which they are found. The origin of strain in olivines from Hawaiian lavas is unclear but may reflect temporary residence in a cumulate pile [Yang et al., 1994] or deformation during magma flow through constricted conduits [Wilkinson and Hensel, 1988].

\section{Source of ${ }^{18} \mathrm{O}$ depletion in Mauna Kea Lavas}

The correlations observed in Figure 2 indicate that the low$\delta^{18} \mathrm{O}$ signature in Mauna Kea lavas is associated with less radiogenic $\mathrm{Sr}$ isotope ratios and more radiogenic $\mathrm{Nd}, \mathrm{Pb}$, and $\mathrm{He}$ isotope ratios compared to those of the higher $-\delta^{18} \mathrm{O}$ Mauna Loa lavas. If we make the usual assumption that "plume" components are richer in ${ }^{3} \mathrm{He}$ and have higher ${ }^{87} \mathrm{Sr} /{ }^{86} \mathrm{Sr}$ (and lower $\varepsilon_{\mathrm{Nd}}$ ) than the "depleted" sources of mid-ocean ridge basalts (MORBs) [Kurz et al., 1983; Hegner et al., 1986; Stille et al., 1986; West et al., 1987], our data provide strong evidence against the hypothesis that low values of $\delta^{18} \mathrm{O}$ in Hawaiian lavas are associated with the relatively enriched isotopic end members commonly associated with the Hawaiian plume [e.g., Garcia et al., 1989, 1993; Harmon and Hoefs, 1995]. Our data show clearly that the enriched (in the sense of $\mathrm{Sr}$ and $\mathrm{Nd}$ isotopes) and primitive (in the sense of He isotopes) "plume" component(s) are preferentially sampled by the Mauna Loa lavas and are associated with $\delta^{18} \mathrm{O}$ values similar to average mantle olivine (based on oxygen isotope analyses of mantle xenoliths and mid-ocean ridge basalts; see below).
Significantly lower $\delta^{18} \mathrm{O}$ values are only found in the Mauna Kea samples, in which the "plume" signature has been diluted by a more depleted and degassed, apparently MORB-like component. Furthermore, olivines in basalts from the Juan Fernandez islands (another location characterized by high, "primitive" ${ }^{3} \mathrm{He} /{ }^{4} \mathrm{He}$ lavas [Farley et al., 1993]) have $\delta^{18} \mathrm{O}$ values of $5.1 \pm 0.1(n=9)$ (Eiler, unpublished results, 1995), also comparable to the upper mantle average. In combination with the data from this study, these results indicate that (1) the high ${ }^{3} \mathrm{He} /{ }^{4} \mathrm{He}$ mantle reservoir(s) sampled in Mauna Loa lavas and elsewhere has a value of $\delta^{18} \mathrm{O}$ for olivine of $5.1-5.2 \%$ (or higher), and (2) the low $\delta^{18} \mathrm{O}$ signature of Mauna Kea lavas and observed in other Hawaiian lavas is derived from a relatively depleted, low ${ }^{3} \mathrm{He} /{ }^{4} \mathrm{He}$ source component.

The isotopic variability of Hawaiian lavas includes two end members that have been previously characterized as "depleted" or MORB-like [Hegner et al., 1986; Stille et al., 1986; West et al., 1987]: one sampled in Mauna Kea lavas (and from other volcanoes on the so-called "Kea" trend) that is distinguished by relatively radiogenic $\mathrm{Pb}\left({ }^{206} \mathrm{~Pb} /{ }^{204} \mathrm{~Pb}>18.4\right)$ and ${ }^{87} \mathrm{Sr} /{ }^{86} \mathrm{Sr}$ ratios only slightly more radiogenic than modern MORB ( $\sim 0.7035$ versus $\sim 0.7028$ ), and the other sampled in post-erosional lavas, which are distinguished by the least radiogenic Sr of Hawaiian lavas $\left({ }^{87} \mathrm{Sr} /{ }^{86} \mathrm{Sr} \sim 0.7032\right)$ and relatively nonradiogenic $\mathrm{Pb}\left({ }^{206} \mathrm{~Pb} /{ }^{204} \mathrm{~Pb} \sim 18.2\right)$. Our data only bear on the origin of the former, "Kea," component. The depleted, MORB-like end member preferentially sampled by 
the "Kea" trend volcanoes has been previously identified with relatively depleted lithospheric and/or entrained asthenospheric upper mantle [e.g., Tatsumoto, 1978; Hegner et ah, 1986; Tatsumoto et al., 1987; Kurz et al., this issue; Lassiter et al., this issue]. If oxygen isotope data from this study are interpreted in these terms, we are left with a paradoxical picture of oxygen isotope heterogeneity in the mantle: The presumably deep-seated, Hawaiian plume component(s) are found in this study to have olivines with a value of $\delta^{18} \mathrm{O}$ $\sim 5.2 \%$. Olivine in a worldwide survey of mantle xenoliths is also known to have an average $\delta^{18} \mathrm{O}$ value of $\sim 5.2 \%$ o [Mattey et al, 1994]. The mantle sources of MORBs yield lavas with an average isotopic composition of 5.7\%o [ Ito et al., 1987], also approximately in equilibrium with olivine having a $\delta^{18} \mathrm{O}$ value of 5.2\%o [Anderson et al., 1971; Muehlenbachs and Kushiro, 1974; Muehlenbachs and Byerly, 1982]. This is also the $\delta^{18} \mathrm{O}$ value of olivine in lunar basalts [Clayton et al., 1971]. A value of $\delta^{18} \mathrm{O}$ of $5.2 \%$ o therefore appears to be a reasonable estimate of the average value for olivine in the upper mantle and perhaps for the entire Earth-Moon system. Lithospheric xenoliths in Hawaiian lavas also have $\delta^{18} \mathrm{O}$ values in the range of the upper mantle average, giving no indication that the oceanic lithosphere beneath Hawaii is anomalously depleted in ${ }^{18} \mathrm{O}$ [Kyser et al., 1982]. The oxygen isotope ratio of sources of "plume"-dominated lavas in Hawaii, although only a lower limit, are therefore indistinguishable from the upper mantle and lunar values. In contrast, the component sampled preferentially in "Kea" trend lavas, which based on its radiogenic isotope ratios has been thought to be derived from upper mantle sources or residues after the extraction of MORBs, has a ${ }^{18} \mathrm{O}$-depleted character quite distinct from known sources of MORBs or any previously documented mantle sources.

If the source of the low- $\delta^{18} \mathrm{O}$ component sampled at Hawaii is a variety of mantle peridotite, then it is not similar to any known MORB source or to the peridotitic lithosphere beneath Hawaii as sampled by xenoliths. Although one could always postulate the existence of an appropriate reservoir, there is no known process of internal differentiation that could produce the required ${ }^{18} \mathrm{O}$-depleted component from normal mantle. Values of $\delta^{18} \mathrm{O}$ of olivine in peridotite xenoliths having depleted chemistries are not significantly lower than those of more fertile lithologies [Mattey et al., 1994], suggesting that extraction of silicate melts does not have a strong influence on oxygen isotope ratios of residual assemblages. This is consistent with the small isotopic fractionation between olivine, pyroxenes, and basalt [Anderson et al., 1971; Muehlenbachs and Kushiro, 1974; Muehlenbachs and Byerly, 1982], which would require that large amounts of melt would have to be extracted in order to form sufficiently ${ }^{18} \mathrm{O}$-depleted residues. Even if sufficiently ${ }^{18} \mathrm{O}-$-depleted residues could be formed in this way, they would likely be too refractory to then produce Mauna Kea shield tholeiites.

An alternative source of the low $\delta^{18} \mathrm{O}$ component is the oceanic crust, the deep portions of which (>1-2 km depth) are known to be low in $\delta^{18} \mathrm{O}$ due to high-temperature exchange with seawater [e.g., Stern et al., 1976; Gregory and Taylor, 1981; Alt et al., 1986]. The oceanic crust contributing to Hawaiian lavas could be either the relatively young (110 Ma [Waggoner, 1993]) Pacific crust through which the lavas have passed en route to the surface or older recycled crust incorporated or entrained in the upwelling plume [e.g., Hofmann and White, 1982]. Neither of these sources can be ruled out at this time. Pacific MORB has $\mathrm{Nd}$ and $\mathrm{Pb}$ isotope compositions similar to but more extreme than those associated with the low $-\delta^{18} \mathrm{O}$ end member seen in Mauna Kea [Ito et al., 1987]. Although the ${ }^{87} \mathrm{~S} \mathrm{r} /{ }^{86} \mathrm{Sr}$ value of this end member is somewhat higher than seen in MORB in the Pacific ( 0.7028 [Clague and Chen, 1986; Ito et al., 1987]), this could be a result of the commonly observed increased radiogenic $\mathrm{Sr}$ content of hydrothermally altered oceanic crust. Other isotopic evidence has been previously interpreted in terms of a key role for assimilated Pacific crust in Hawaiian lavas [Kyser and O'Neil, 1984; Hegner et al., 1986; Tatsumoto et al., 1987; Chaussidon and Jambon, 1994; Chaussidon and Marty, 1995], and this is plausible given the high inferred temperatures and olivine-rich character of primitive Hawaiian tholeiitic liquids [Garcia et al., 1995b] and petrological and geophysical evidence for ponding of lavas at the level of the old oceanic crust beneath Hawaiian volcanoes [ten Brink and Broecher, 1987; Clague, 1987]. However, since eclogite xenoliths are frequently ${ }^{18} \mathrm{O}$-depleted [Garlick et al., 1971; Nadeau et al., 1993], suggesting that portions of the oceanic crust are low in $\delta^{18} \mathrm{O}$ after subduction, recycled oceanic crust could also be an acceptable source for the distinctive ${ }^{18} \mathrm{O}$-depleted character of the Mauna Kea lavas. The radiogenic isotope characteristics of old recycled oceanic crust are difficult to anticipate, but unless nearly all the $\mathrm{Rb}, \mathrm{Sm}, \mathrm{U}$, and Th are stripped from the oceanic crust during subduction or the recycling time of this ancient crust is relatively short, it would be difficult to explain how the $\mathrm{Sr}, \mathrm{Nd}$, and $\mathrm{Pb}$ isotope ratios would so closely approach those of young MORB, as is observed for ${ }^{18} \mathrm{O}$ depleted Mauna Kea lavas. Although it is not possible to resolve unambiguously whether recycled oceanic crust or the lower parts of the Pacific oceanic crust underlying Hawaii would be more satisfactory as a source of the ${ }^{18} \mathrm{O}$-depleted "Kea" trend lavas, the results of this study suggest that the "depleted" source component of Hawaiian shield-building lavas may be basic rather than ultrabasic in composition (i.e., basalt, gabbro, or eclogite rather than peridotite).

Acknowledgments. We gratefully acknowledge helpful reviews of this manuscript by Don DePaolo, Bruce Nelson, Mark Conrad, Ken Farley, Mike Garcia, Nuni-Lyn Anders, and Peter Reiners. We also thank Mike Garcia for providing additional samples of Mauna Kea analyzed for comparison with the samples from the HSDP core; Mike Baker, Erik Hauri, Al Hofmann, Mark Kurz, John Lassiter, and Mike Rhodes for providing isotopic and compositional data on samples from the HSDP core prior to their publication in this special section; and Mike Spicuzza and Nami Kitchen for assistance in the stable isotope laboratory at the University of Wisconsin. This work was supported in part by NSF grant EAR-9117588 supporting the HSDP project and grants from DOE (93ER 14389 to J.W.V., DEFG03-85ER13445 to E.M.S.) and NSF (93-04372 to J.W.V., EAR 93-03975 to E.M.S.). Caltech Division of Geological and Planetary Sciences contribution 5541.

\section{References}

Alt, J.C., K. Muehlenbachs, and J. Honnorez, An oxygen isotopic profile through the upper kilometer of the oceanic crust, DSDP hole 504B, Eurth Planet. Sci. Lett., 80, 217-229, 1986.

Anderson, A.T., R.N. Clayton, and T.K. Mayeda, Oxygen isotope thermometry of mafic igneous rocks, J. Geol., 79, 714-729, 1971.

Baker, M.B., S. Alves, S. Newman, and E.M. Stolper, Petrology and petrography of the Hawaii Scientific Drilling Project lavas: Inferences from olivine phenocryst abundances and compositions, $J$. Geophys. Res. , this issue.

Cartwright, I., and J.W. Valley, Low- ${ }^{18} \mathrm{O}$ Scourie dike magmas from the Lewisian complex, NW Scotland, Geology, 19, 578-581, 1991.

Chaussidon, M., and A. Jambon, Boron content and isotopic composition of oceanic basalts: geochemical and cosmochemical implication, Earth Planet. Sci. Lett., 121, 277-291, 1994.

Chaussidon, M., and B. Marty, Primitive boron isotope composition of the mantle, Science, 269, 383-386, 1995. 
Clague, D.A., Hawaiian xenolith populations, magma supply rates, and development of magma chambers, Bull. Volcanol., 49, 577-587, 1987.

Clague, D.A., and C.H. Chen, Ocean crust xenoliths from Haulalaj volcano, Hawaii, Geol. Soc. Am. Abstr. Programs, 18, 565, 1986.

Clague, D.A., and R.P. Denlinger, Role of olivine cumulates in destabilizing the flanks of Hawaiian volcanoes, Bull. Volcanol., 56, 425-434, 1994.

Clayton, R.N., N. Onuma, and T.K. Mayeda, Oxygen isotope fractionation in Apollo 12 rocks and soils, Proc. $2^{\text {nd }}$ Lunar Sci. Conf., 1417-1420, 1971.

Farley, K.A., A.R. Basu, and H. Craig, He, Sr and Nd isotopic variations in lavas from the Juan Fernandez archipelago, SE Pacific, Contrib. Mineral. Petrol., 115, 75-87, 1993.

Garcia, M.O., Petrography and olivine and glass chemistry of lavas from the Hawaii Scientific Drilling Project, J. Geophys. Res., this issue.

Garcia, M.O., D.W. Muenow, K.E. Aggrey, and J.R. O'Neil, Major element, volatile and stable isotope geochemistry of Hawaiian submarine tholeiitic glasses, J. Geophys. Res. , 94, 10,525-10,538, 1989.

Garcia, M.O., B.A. Jorgenson, and J.J. Mahoney, An evaluation of temporal geochemical evolution of Loihi summit lavas: results from Alvin submersible dives, J. Geophys. Res., 98, 537-550, 1993.

Garcia,, M.O., A. Pietruszka, E. Ito, and J. Eiler, Oxygen isotope variations in lavas from the ongoing Puu Oo eruption of Kilauea volcano, EOS Trans. AGU, 76(46), Fall Meet. Suppl., F664, 1995 a.

Garcia, M.O., T.P. Hulsebosch, and J.M. Rhodes, Olivine-rich submarine basalts from the southwest rift zone of Mauna Loa volcano: Implications for magmatic processes and geochemical evolution, in: Mauna Loa Revealed: Structure, Composition, History, and Hazards, Geophys. Monogr. Ser., vol. 92, edited by J.M. Rhodes and J.P. Lockwood, pp. 219-239, AGU, Washington, D.C., $1995 b$.

Garlick, G.D., I.D. MacGregor, and D.E. Vogel, Oxygen isotope ratios in eclogites from kimberlites, Science, 172, 1025-1027, 1971.

Gregory, R.T., and H.P. Taylor, An oxygen isotope profile in a section of Cretaceous oceanic crust, Samail ophiolite, Oman: Evidence for $\delta^{18} \mathrm{O}$ buffering of the oceans by deep ( $>5 \mathrm{~km}$ ) seawaterhydrothermal circulation at mid-ocean ridges, J. Geophys. Res., 86, 2737-2755, 1981.

Harmon, R.S., and J. Hoefs, Oxygen isotope heterogeneity of the mantle deduced from global ${ }^{18} \mathrm{O}$ systematics of basalts from different geotectonic settings, Contrib. Mineral. Petrol., 120, 95 114, 1995.

Hauri, E.H., J.C. Lassiter, and D.J. DePaolo, Osmium isotope systematics of drilled lavas from Mauna Loa, Hawaii, J. Geophys. Res. , this issue.

Hegner, E., D. Unruh, and M. Tatsumoto, Nd-Sr-Pb isotope constraints on the sources of West Maui volcano, Hawaii, Nature, 319, 478$480,1986$.

Helz, R.T., Diverse olivine types in lava of the 1959 eruption of Kilauea volcano and their bearing on eruption dynamics, U.S. Geol. Surv. Prof. Pap., 1350, 691-721, 1987.

Hemond, C., N.T. Arndt, U. Lichtenstein, and A.W. Hofmann, The heterogeneous Iceland Plume: $\mathrm{Nd}-\mathrm{Sr}-\mathrm{O}$ isotopes and trace element constraints, J. Geophys. Res., 98, 15,833-15,850, 1993.

Hofmann, A.W., and K.P. Jochum, Source characteristics derived from very incompatable trace elements in Mauna Loa and Mauna Kea basalts, Hawaii Scientific Drilling Project, J. Geophys. Res., this issue.

Hofmann, A.W., and W.M. White, Mantle plumes from ancient oceanic crust, Earth Planet. Sci. Lett., 57, 421-436, 1982.

Ito, E., W.M. White, and C. Gopel, The $\mathrm{O}, \mathrm{Sr}, \mathrm{Nd}$ and $\mathrm{Pb}$ isotope geochemistry of MORB, Chem. Geol., 62, 157-176, 1987.

Kurz, M.D., W.J. Jenkins, S.R. Hart, and D. Clague, Helium isotopic variations in volcanic rocks from Loihi seamount and the island of Hawaii, Earth Planet. Sci. Lett., 66, 388-406, 1983.

Kurz, M.D., T.C. Kenna, J.C. Lassiter, and D.J. Depaolo, Helium isotopic evolution of Mauna Kea volcano: First results from the 1 km drill core, J. Geophys. Res., this issue.

Kyser, T.K., and J.R. O'Neil, Hydrogen isotope systematics of submarine basalts, Geochim. Cosmochim. Acta, 48, 2123-2133, 1984.

Kyser, T.K., J.R. O'Neil, and I.S.E. Carmichael, Genetic relations among basic lavas and ultramafic nodules: Evidence from oxygen isotope compositions, Contrib. Mineral. Petrol., 81, 88-102, 1982.
Lassiter, J.C., D.J. Depaolo, and M. Tatsumoto, Isotopic evolution of Mauna Kea volcano: Results from the initial phase of the Hawaiian Scientific Drilling Project, J. Geophys. Res., this issue.

Mattey, D., and C.M. Macpherson, High-precision oxygen isotope analysis of microgram quantities of silicate by laser-fluorination, Chem. Geol., I05, 305-318, 1993.

Mattey, D., D. Lowry, and C. Macpherson, Oxygen isotope composition of mantle peridotite, Earth Planet. Sci. Lett., 128, 231 241, 1994.

Muehlenbachs, $\mathrm{K}$., and $\mathrm{G}$. Byerly, ${ }^{18} \mathrm{O}$ enrichment of silicic magmas caused by crystal fractionation at the Galapagos spreading center, Contrib. Mineral. Petrol., 79, 76-79, 1982.

Muehlenbachs, K, and I. Kushiro, Oxygen 1sotope exchange and equilibrium of silicates with $\mathrm{CO}_{2}$ or $\mathrm{O}_{2}$, Carnegie Inst. Washington Year Book, 7l, 232-236, 1974.

Nadeau, S., P. Philippot, and F. Pineau, Fluid inclusion and mineral isotopic compositions (H-C-O) in eclogitic rocks as tracers of local fluid migration during high-pressure metamorphism, Earth Planet. Sci. Lett., I14, 431-448, 1993.

Rhodes, J.M., Geochemical stratigraphy of lava flows sampled by the Hawaii Scientific Drilling Project, J. Geophys. Res., this issue.

Sharp, Z.D., A laser based microanalytical method for the in situ determination of oxygen isotope ratios of silicates and oxides, Geochim. Cosmochim. Acta, 54, 1353-1357, 1990.

Sigmarsson, O., M. Condomines, and S. Fourcade, A detailed $\mathrm{Th}, \mathrm{Sr}$ and $O$ isotope study of Hekla: Differentiation processes in an Icelandic volcano, Contrib. Mineral. Petrol., 112, 20-34, 1992.

Stern, C., M.J. deWit, and J.R. Lawrence, Igneous and metamorphic processes associated with the formation of Chilean ophiolites and their implication for ocean floor metamorphism, seismic layering, and magnetism, J. Geophys. Res., 81, 4370-4380, 1976.

Stille, P., D.M. Unruh, and M. Tatsumoto, $\mathrm{Pb}, \mathrm{Sr}, \mathrm{Nd}$ and $\mathrm{Hf}$ isotopic constraints on the origin of Hawaiian basalts and evidence for a unique mantle source, Geochim. Cosmochim. Acta, 50, 2303-2319, 1986.

Stolper, E.M., D. DePaolo, and D. Thomas, The Hawaii Scientific Drilling Project: Introduction to the special section, J. Geophys. Res., this issue.

Tatsumoto, M., Isotopic composition of lead in oceanic basalt and its implication to mantle evolution, Earth Planet. Sci. Lett., 38, 63-87, 1978.

Tatsumoto, M., E. Hegner, and D.M. Unruh, Origin of the west Maui volcanic rocks inferred from $\mathrm{Pb}, \mathrm{Sr}$ and $\mathrm{Nd}$ isotopes and a multicomponent model for oceanic basalt, U.S. Geol. Surv. Prof. Pap., 1350, 723-744, 1987.

ten Brink, U.S., and T.M. Broecher, Multichannel seismic evidence for a subcrustal intrusive complex under Oahu and a model for Hawaiian volcanism, J. Geophys. Res., 92, 13,687-13,707, 1987.

Valley, J.W., N. Kitchen, M.J. Kohn, C.R. Niendorf, and M.J. Spicuzza, UWG-2, a garnet standard for oxygen isotope ratio: Strategies for high precision and accuracy with laser heating, Geochim. Cosmochim. Acta, 59, 5223-5231, 1995.

Waggoner, D.G., The age and alteration of central Pacific oceanic crust, Proc. Ocean Drill. Program, Sci. Results, 136, 119-132, 1993.

West, H.B., D.C. Gerlach, W.P. Leeman, and M.O. Garcia, Isotopic constraints on the origin of Hawaiian lavas from the Maui volcanic complex, Hawaii, Nature, 330, 216-220, 1987.

Wilkinson, J.F.G., and H.D. Hensel, The petrology of some picrites from Mauna Loa and Kilauea volcanoes, Hawaii, Contrib. Mineral. Petrol., 98, 326-345, 1988.

Yang, H.-J., F.A. Frey, M.O. Garcia, and D.A. Clague, Submarine lavas from Mauna Kea Volcano, Hawaii: Implications for Hawaiian shield stage processes, J. Geophys. Res., 99, 15,577-15594, 1994.

Yang, H.-J., F.A. Frey, J.M. Rhodes, and M.O. Garcia, Evolution of Mauna Kea volcano: Inferences from lava compositions recovered in the Hawaii Scientific Drilling Project, J. Geophys. Res., this issue.

Zindler, A., and S.R. Hart, Chemical Geodynamics, Ann. Rev. Earth Planet. Sci. , 14, 493-571, 1986.

J. Eiler and E.M. Stolper, Division of Geological and Planetary Sciences, California Institute of Technology, Pasadena, CA 91125 (email: eiler@expet.gps.caltech.edu; ems@expet.gps.caltech.edu)

J.W. Valley, Department of Geology and Geophysics, University of Wisconsin, Madison, WI 53706 (e-mail: valley@geology.wisc.edu)

(Received May 15, 1995; revised October 4, 1995;

accepted October 11, 1995) 